\title{
AN UNUSUAL SUITE OF INCLUSIONS IN DIAMONDS FROM NAMIBIA
}

\author{
Leost $\mathbf{I}^{1}$, Stachel $\mathbf{T}^{2}$, Brey $\mathbf{G P}^{\mathbf{1}}$ and Harris* $\mathbf{J W}^{\mathbf{3}}$ \\ ${ }^{1}$ University of Frankfurt, Germany; ${ }^{2}$ University of Alberta, Edmonton, Canada $;{ }^{3}$ University of Glasgow, UK.
}

\section{INTRODUCTION}

The placer deposits along the Namibian coast have been mined for almost a century and have consistently produced a high proportion of gem quality diamonds. Little is known, however, about their inclusion parageneses and their primary origin. We have now undertaken a detailed study on 106 inclusion-bearing diamonds from Namibia from which 49 belong to the "normal" peridotitic and 43 to the "normal" eclogitic suites. One other contains a websterite-eclogite inclusion. The remaining 13 belong to an unusual and hitherto unknown suite ("undetermined suite") of lamellar intergrowths of pyroxenes associated with minerals normally observed in mantle xenoliths with a special type of metasomatism. Amongst these are carbonates, phlogopite and a Ba-titanate. In this presentation we concentrate on these unusual diamonds and their inclusions.

\section{MINERALOGY}

The characteristic feature of diamonds of the "undetermined suite" is the occurrence of pyroxene associations with unusual textures (Figure 1). Clinopyroxene and orthopyroxene intergrown as lamellae or in patches were observed in nine diamonds. In six of these diamonds the pyroxenes are associated with other minerals: a $\mathrm{SiO}_{2}$ phase (two diamonds), $\mathrm{MgCO}_{3}$ (one diamond), $\mathrm{CaCO}_{3}$ (one diamond, together with $\mathrm{SiO}_{2}$ ), phlogopite (one diamond) and an unusual Ti-rich phase (one diamond, together with a $\mathrm{Ca}$ - and Cr-rich garnet). The complete absence of olivine and of garnet (except for one) is conspicuous. The former must mean that $\mathrm{SiO}_{2}$-oversaturation is a common feature of the whole suite, the latter is due to the Al-poor and Crrich nature of the suite (see below).

\section{MINERAL CHEMISTRY}

The lamellar intergrowths of ortho- and clinopyroxene shown in Fig. 1 are interpreted as exsolution lamellae that originated from homogeneous inclusions of low-Ca clinopyroxene. Two compositional trends, most clearly seen in the clinopyroxenes, are apparent in Fig. 2: (i) high-Ca (low-Na) group with a range in Mg-values and corresponding orthopyroxenes (low $\mathrm{Ca}$ and $\mathrm{Na}$ ), and (ii) low-Ca (high-Na) group with corresponding high-Ca and $-\mathrm{Na}$ orthopyroxenes which shows a range extending
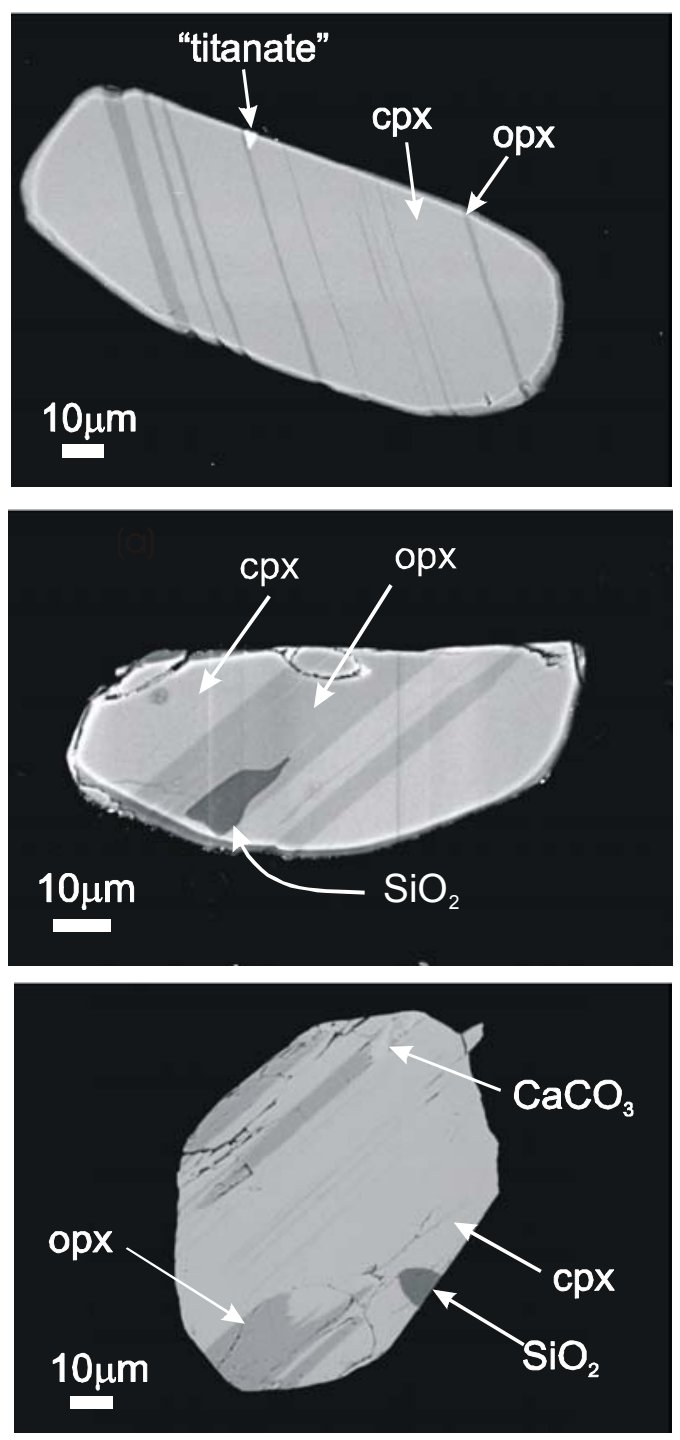

Figure 1: BSE images of typical inclusions of the "undetermined suite". The main feature is lamellar intergrowth of clinopyroxene (cpx) and orthopyroxene (opx) interpreted as exsolution of opx from a former low$\mathrm{Ca}$ cpx. Shown here are only inclusions containing additional phases such as a "titanate" (top), $\mathrm{SiO}_{2}$, probably coesite (middle) and $\mathrm{SiO}_{2}$ plus Ca-carbonate, probably aragonite (bottom). 


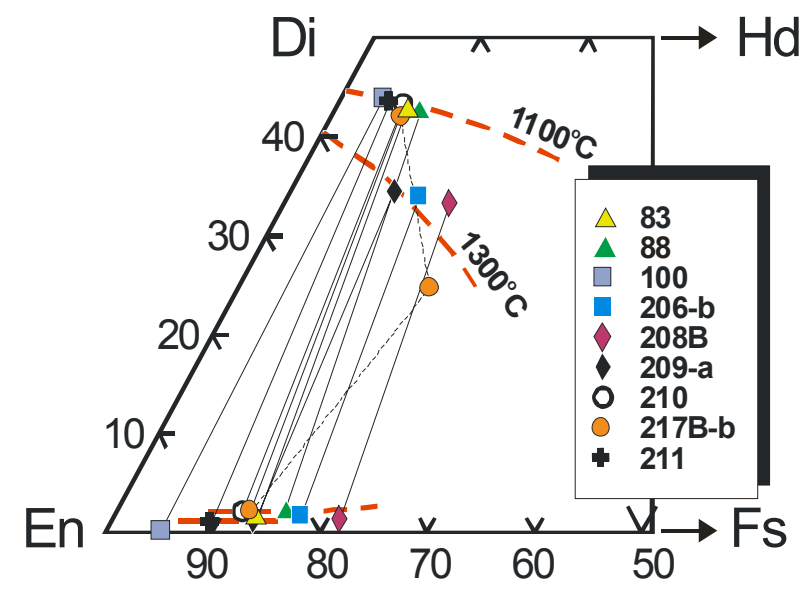

Figure 2: Compositions of pyroxene intergrowths and one

to even lower Mg-values (see also Figs 3 and 4).

The worldwide data base for orthopyroxene inclusions shows the vast majority to lie in a field of Mg-numbers ranging from 91 to 97 with $\mathrm{Cr}_{2} \mathrm{O}_{3}, \mathrm{NiO}$ and $\mathrm{Na}_{2} \mathrm{O}$ contents between $0.02-0.75,0.08-0.16$ and $\leq 0.02-0.08$ $\mathrm{wt} \%$ respectively. "Normal" peridotitic orthopyroxenes from Namibian placer deposits fully overlap with this range. Some orthopyroxenes of the "undeterminedsuite" overlap with the lower tail-end of the worldwide database in $\mathrm{Mg}$-values. Others have significantly higher $\mathrm{Cr}_{2} \mathrm{O}_{3}, \mathrm{NiO}$ and $\mathrm{Na}_{2} \mathrm{O}$ contents, (Fig. 3). These geochemical features are mirrored in the clinopyroxenes (Fig. 4) with some very high $\mathrm{Cr}$ contents correlating with $\mathrm{Na}_{2} \mathrm{O}$ in the high- $\mathrm{Na}_{2} \mathrm{O}$ group, with high overall $\mathrm{NiO}$ contents and high $\mathrm{K}_{2} \mathrm{O}$. Particularly high concentrations of $\mathrm{Cr}$ (at high $\mathrm{Na}$ ) are observed in a clinopyroxene with an Mg-number of 85. Clinopyroxenes with higher $\mathrm{Cr}$ at similar $\mathrm{Na}$ contents have so far only been reported from two other diamonds worldwide (Arkhangelsk, Sobolev et al. 1997c; Dokolwayo, Daniels and Gurney 1999) and from a metasomatised peridotite xenolith from the Siberian Craton (Sobolev et al. 1997b).

In one diamond, a green garnet and a "titanate" inclusion phase coexist with an opx-cpx intergrowth. Green lherzolitic garnets owe their colour to significant contents of both the knorringite and uvarovite component and are rare in diamonds and xenoliths (Schulze 1987). This garnet is distinct from other Namibian lherzolitic garnets because of a low Mgnumber and high $\mathrm{Cr}_{2} \mathrm{O}_{3}$ and $\mathrm{TiO}_{2}$ contents. The composition of the very small Cr-rich "titanate" is not well determined because analytical overlap with the surrounding pyroxenes could not be avoided. The



Figure 3: Compositional features of orthopyroxenes from the "undetermined suite" (stars) shown in comparison to a database for inclusions in diamonds from worldwide sources (for references see Stachel et al. 2000) and orthopyroxenes from the peridotitc suite from Namibia (open triangles, Stachel et al., in prep.) 
titanate seems to correspond to $\mathrm{Cr}$-rich lindsleyite, the barium end-member of the LIMA series (Haggerty et al. 1983). Its stability field extends across the graphitediamond transition (Foley et al. 1994) and its occurrence is indicative of strongly metasomatised mantle domains (Haggerty et al. 1983). Lindsleyite was

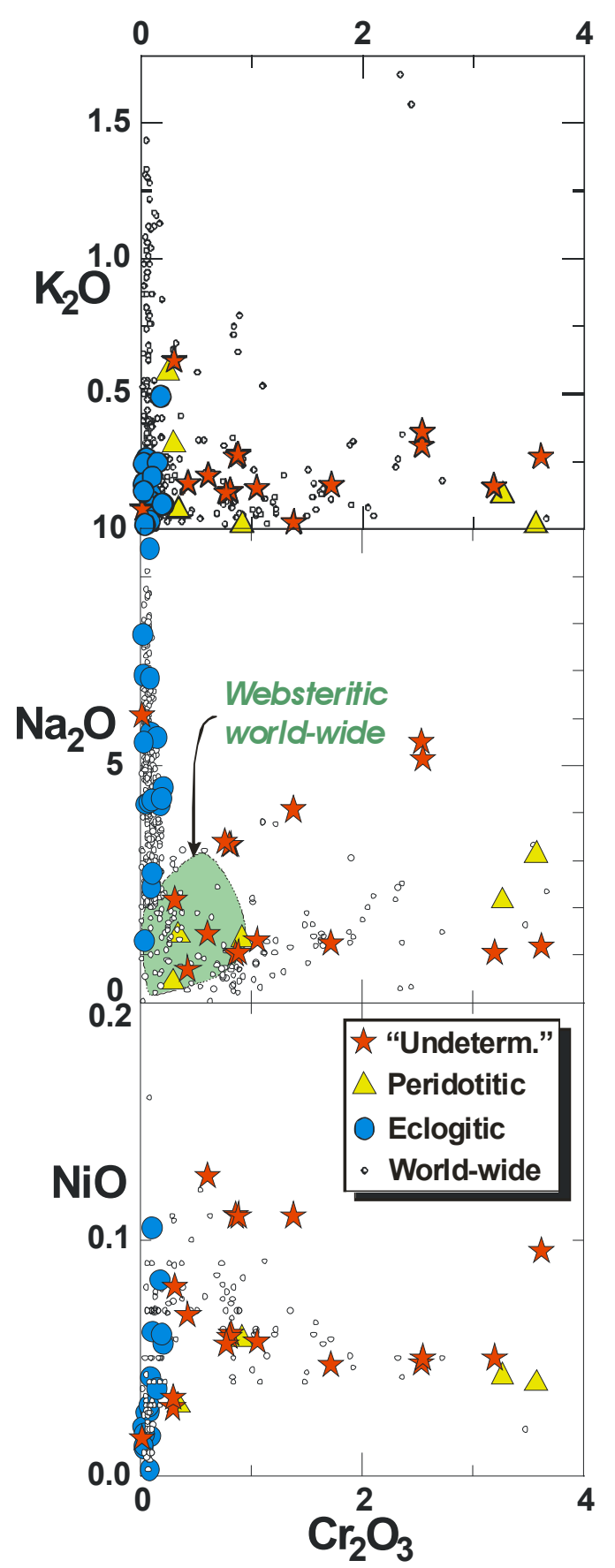

Figure 4: clinopyroxene inclusions from the "undetermined suite" shown in comparison to peridotitic and eclogitic clinopyroxenes from Namibia (Stachel et al., in prep.) and a worldwide database for inclusions in diamonds previously reported as an inclusion in diamond from the Siberian Craton (Sobolev et al. 1997a).

Magnesite and aragonite are also stable within the diamond stability field (Wyllie and Huang 1976; Brey et al. 1983). The higher Mg-number of magnesite compared to those of coexisting pyroxenes is due to the preferential partitioning of $\mathrm{Mg}$ over $\mathrm{Fe}$ in carbonates as compared to silicates (Brey and Green 1976; Wallace and Green 1988). Magnesite was previously reported as an inclusion in diamond by Wang et al. (1996) and assumed to be of primary origin and $\mathrm{CaCO}_{3}$ was recorded in several diamonds (McDade and Harris 1999 -with olivine Fo95; Sobolev et al. 1997a -intergrown with phlogopite of eclogitic paragenesis).

\section{GEOTHERMOBAROMETRY}

Equilibration temperatures of coexisting clinopyroxene and orthopyroxene were estimated with the twopyroxene thermometer $\left(\mathrm{T}_{B K N}\right)$ of Brey and Köhler (1990). A pressure of $50 \mathrm{kbar}$ was assumed and results are shown in Fig. 5. Equilibration temperatures fall into two distinct groups, with the high-Na pyroxene intergrowths indicating high (average $=1292^{\circ} \mathrm{C}$ ) and the low-Na group low temperatures (average = $1167^{\circ} \mathrm{C}$ ). But these temperatures do not reflect the conditions likely during diamond formation. If the intergrowth lamellae are due to exsolution, orthopyroxene must have exsolved from a formerly homogeneous clinopyroxene (with no coexisting orthopyroxene) as orthopyroxene with clinopyroxene lamellae are not observed. Modal recombination yields the original clinopyroxene composition for which minimum temperatures of formation can be calculated. This has been done for 5 samples and the temperatures obtained for the recombined low-Ca clinopyroxenes are 200 to $300{ }^{\circ} \mathrm{C}$ higher then the temperatures calculated for the intergrowths. These temperatures are high compared to those derived for touching pairs of inclusions worldwide and which fall along conductive continental geotherms. They are, however, within the high temperature range of a considerable number of non-touching inclusions (Girnis et al. 1999).

A further calculation can be made with the diamond containing garnet as a single inclusion, in addition to two orthopyroxene-clinopyroxene-intergrowths (one of them co-existing with lindsleyite). Iterative computing based on a combination of $\mathrm{P}_{B K N}$ with both $\mathrm{T}_{B K N}$ and $\mathrm{T}_{\text {Harley }}$ (Harley 1984) consistently give an estimate of about $1220^{\circ} \mathrm{C}$ and $48-49 \mathrm{kbar}$. The application of a cpxgrt thermometer (in the version of Krogh 1988) gives a temperature of about $1320^{\circ} \mathrm{C}$ at an assumed pressure of 48 kbar. This temperature must approach the original 


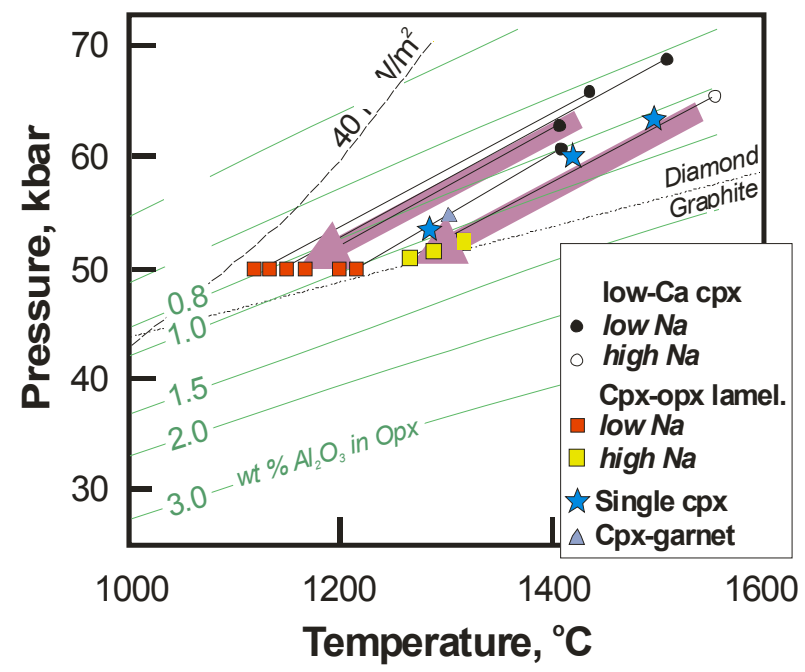

Figure 5: Inferred conditions of crystallisation and cooling path for the cpx-opx lamellar intergrowths and for the three single cpx inclusions (open stars). Filled circles are inferred growth conditions for recombined clinopyroxenes of the low-Na group, open circle is an estimate for one high-Na cpx. Closed and open squares are temperature estimates for the lamellar intergrowths of the low- and high-Na group respectively. The open triangle is the Fe$\mathrm{Mg}^{\text {cpx/grt }}$ temperature estimate for a sample containing garnet as well.

All temperatures were calculated for $50 \mathrm{kbar}$. Pressures for the recombined cpx compositions seen in the diagram were selected such that lines connecting these points with the temperatures for the intergrowths have a steeper slope than the Al-isopleths for orthopyroxene. Also shown are a conductive continental geotherm and Al-isopleths in orthopyroxene for a lherzolitic composition with $\mathrm{Cr} /(\mathrm{Cr}+\mathrm{Al})^{\text {garnet }}=0.2, \mathrm{Ca} /(\mathrm{Ca}+\mathrm{Mg}+\mathrm{Fe})^{\text {garnet }}=0.05$ and olivine with $\mathrm{Fo}_{0.9}$. The shaded arrows are suggested cooling paths.

crystallization temperature, since the partitioning of $\mathrm{Fe}$ and $\mathrm{Mg}$ between orthopyroxene and clinopyroxene is close to unity at these conditions and thus, the temperature for the original cpx-grt pair cannot differ by much. The temperature calculated for the integrated clinopyroxene-orthopyroxene intergrowth gives about $1415^{\circ} \mathrm{C}$ (orthopyroxene-lamellae are thin and make up only 14\%). This particular diamond therefore, must have crystallized at around $1400^{\circ} \mathrm{C}$ at pressures above $50 \mathrm{kbar}$ with subsequent cooling to about $1220^{\circ} \mathrm{C}$ along a P, T-trajectory which does not allow exsolution of garnet from the opx-cpx-intergrowth. This requires the P,T-slope to be steeper than that of Al-in-opx isopleths (Fig. 5). Such a cooling path also must apply to all other exsolved inclusions since garnet was not observed as an exsolving phase.

Minimum temperature estimates with $\mathrm{T}_{\mathrm{BKN}}$ at $50 \mathrm{kbar}$ were also derived for the three lamellae-free clinopyroxene inclusions considered to belong to the "undetermined suite". They also give high temperatures of $1503{ }^{\circ} \mathrm{C}$ and $1393{ }^{\circ} \mathrm{C}$ for the Na-rich samples and $1298^{\circ} \mathrm{C}$ for the Na-poorer sample.

\section{DISCUSSIONS AND CONCLUSIONS}

The "undetermined suite" of inclusions in Namibian diamonds is characterized by (i) exsolution of orthopyroxene from former homogeneous clinopyroxene and (ii) $\mathrm{SiO}_{2}$-saturation or oversaturation (absence of olivine), but nonetheless, (iii) has peridotitic fingerprints like high $\mathrm{Ni}$ and $\mathrm{Cr}$ in pyroxene and garnet, and occurrence of a Cr-rich "titanate". The "undetermined suite" is further characterized by low Mg-values, high $\mathrm{K}, \mathrm{Ba}$ and $\mathrm{Sr}$ and can be divided into a high and a low sodium group. Its members show both peridotitic and eclogitic (websteritic) features. It further contains $\mathrm{CaCO}_{3}$, $\mathrm{MgCO}_{3}$, phlogopite and lindsleyite as "accessories" and $\mathrm{SiO}_{2}$ as exsolutions from the pyroxenes.

The "cubo-octahedral shape" of the orthopyroxeneclinopyroxene intergrowths suggests that they are syngenetic inclusions, implying that the exsolution process postdates encapsulation in the diamond. The inclusions originally consisted of low-Ca clinopyroxene with a Ca-Eskola component together with minor amounts of carbonate, lindsleyite, phlogopite and garnet. The inclusions and their host diamonds crystallized at elevated temperatures of about 1300 to $1500{ }^{\circ} \mathrm{C}$ and probably pressures between 60 and 70 kbar. This occurred during events of interaction of a hot, $\mathrm{CO}_{2}$-rich (carbonate-rich) melt/fluid and mantle peridotite at oxygen fugacities of the CCO-buffer. They subsequently cooled back towards a conductive continental geotherm along P,T trajectories which did not allow garnet exsolution to accompany exsolution of orthopyroxene (Fig. 5). Locally the cratonic lithospheric mantle must have been virtually flooded by the $\mathrm{CO}_{2}$-rich melt/fluid to eliminate all olivine by carbonation reactions.

At some depth a critical point for the system lherzolite$\mathrm{CO}_{2}-\mathrm{H}_{2} \mathrm{O}$ may exist and continuity between dolomitic melts and aqueous fluids may occur (Wyllie and Ryabchikov 2000). Hence, metasomatic agents occurring in the diamond stability field at oxygen fugacities of the CCO-buffer may be $\mathrm{CO}_{2}$-rich melts (carbonatites) or supercritical fluids. This agent carries incompatible elements like $\mathrm{K}, \mathrm{Ba}$ and $\mathrm{Na}$ and also $\mathrm{Ca}$ and $\mathrm{Fe}$ (to explain the range in Mg-values), but must be low in Al. In a study of metasomatised peridotites, Erlank et al. (1987) observed that LIMA phases coexisting with phlogopite were restricted to samples where metasomatic overprint is most effective, i.e. in 
harzburgites. In compliance with Jones (1982) they suggested that the Cr-rich "titanates" grew by metasomatic replacement of $\mathrm{Cr}$-rich spinels. This is also a viable explanation for the presumed LIMA phase in diamond Nam-217B.

\section{REFERENCES}

Brey, G.P. et al., 1983. Pyroxene-carbonate reactions in the upper mantle. Earth. Planet. Sci. Lett., 62: 63-74.

Brey, G.P. and Green, D.H., 1976. Solubility of $\mathrm{CO}_{2}$ in olivine melilitite at high pressures and the role of $\mathrm{CO}_{2}$ in the Earth's upper mantle. Contrib. Mineral. Petrol., 55: 217-230.

Brey, G.P. and Köhler, T., 1990. Geothermobarometry in four-phase lherzolites II. New thermobarometers, and practical assessment of existing thermobarometers. J. Petrol., 31: 1353-1378.

Daniels, L.R. and Gurney, J.J., 1999. Dokolwayo diamond carbon isotopes. In: J.J. Gurney, J.L. Gurney, M.D. Pascoe and S.H. Richardson (Editors), The J.B. Dawson Volume, Proceedings of the VIIth International Kimberlite Conference. Red Roof Design, Cape Town, pp. 143-147.

Erlank, A.J. et al., 1987. Evidence for mantle metasomatism in peridotite nodules from the Kimberley pipes, South Africa. In: M. A. Menzies and C.J. Hawkesworth (Editors), Mantle Metasomatism. Academic Press, London, pp. 221-311.

Foley, S., Höfer, H. and Brey, G., 1994. High-pressure synthesis of priderite and members of the lindsleyite-mathiasite and hawthorneiteyimengite series. Contrib. Mineral. Petrol., 117: 164-174.

Girnis, A.V., Stachel, T., Brey, G.P., Harris, J.W. and Phillips, D., 1999. Internally consistent geothermobarometers for garnet harzburgites: model refinement and application. In: J.J. Gurney, J.L. Gurney, M.D. Pascoe and S.H. Richardson (Editors), The J.B. Dawson Volume, Proceedings of the VIIth International Kimberlite Conference. Red Roof Design, Cape Town, pp. 247-254.

Haggerty, S.E., Smyth, J.R., Erlank, A.J., Rickard, R.S. and Danchin, R.V., 1983. Lindsleyite (Ba) and mathiasite $(\mathrm{K})$ - two new chromium-titanates in the crichtonite series from the upper mantle. Amer. Mineral., 68: 494-505.

Harley, S.L., 1984. An experimental study of the partitioning of iron and magnesium between garnet and orthopyroxene. Contrib. Mineral. Petrol., 86: 359-373.

Jones, A.P., 1982. Upper-mantle enrichment by kimberlitic or carbonatitic magmatism. In: K. Bell (Editor), Carbonatites, genesis and evolution, pp. 448-463.

Krogh, E., 1988. The garnet-clinopyroxene ironmagnesium geothermometer - a reinterpretation of existing experimental data. Contrib. Mineral. Petrol., 99: 44-48.

McDade, P. and Harris, J.W., 1999. Syngenetic inclusion bearing diamonds from Letseng-laTerai, Lesotho. In: J.J. Gurney, J.L. Gurney, M.D. Pascoe and S.H. Richardson (Editors), The P.H. Nixon Volume, Proceedings of the VIIth International Kimberlite Conference. Red Roof Design, Cape Town, pp. 557-565.

Schulze, D.J., 1989. Green garnets from South African kimberlites and their relationship to wehrlites amd crustal uvaravites. In: J. Ross and et al. (Editors), Kimberlites and related rocks. GSA Spec Publ 14. Blackwell, Carlton, pp. 820826.

Sobolev, N.V. et al., 1997a. Mineral inclusions in diamonds from the Sputnik kimberlite pipe, Yakutia. Lithos, 39: 135-157.

Sobolev, V.N. et al., 1997b. A unique metasomatized peridotite xenolith from the Mir kimberlite pipe (Yakutia). Geol. Geofiz., 38: 206-215.

Sobolev, N.V. et al., 1997c. Mineral inclusions in the diamonds of Arkhangelsk kimberlite province. Russian Geology and Geophysics, 38: 379393.

Stachel, T., Brey, G.P. and Harris, J.W., 2000. Kankan diamonds (Guinea) I: from the lithosphere down to the transition zone. Contrib. Mineral. Petrol., 140: 1-15.

Wallace, M.E. and Green, D.H., 1988. An experimental determination of primary carbonatite magma composition. Nature, 335(6188): 343-346.

Wang, A., Pasteris, J.D., Meyer, H.O.A. and DeleDuboi, M.L., 1996. Magnesite-bearing inclusion assemblage in natural diamond. Earth. Planet. Sci. Lett., 141: 293-306.

Wyllie, P.J. and Huang, W.-L., 1976. Carbonation and melting reactions in the system $\mathrm{CaO}-\mathrm{MgO}-$ $\mathrm{SiO} 2-\mathrm{CO} 2$ at mantle pressures with geophysical and petrological applications. Contrib. Mineral. Petrol., 54: 79-107.

Wyllie, P.J. and Ryabchikov, I.D., 2000. Volatile components, magmas, and critical fluids in upwelling mantle. J. Petrol., 41: 1195-1206.

Contact: JW Harris, Division of Earth Sciences, Univ. of Glasgow, G12 8QQ, UK, E-mail jwh@earthsci.gla.ac.uk 